\title{
In-Vitro Production of Anthocyanin in Sesbania grandiflora (Red Katuray) as Influenced by Varying Concentrations of 2,4-D and BA Added on MS Medium
}

\author{
Donata A. Largado-Valler \\ College of Agriculture, Dr. Emilio B. Espinosa Sr. Memorial State College of Agriculture and Technology, Mandaon, Philippines \\ Email: donatavaller@yahoo.com
}

How to cite this paper: Largado-Valler, D.A. (2016) In-Vitro Production of Anthocyanin in Sesbania grandiflora (Red Katuray) as Influenced by Varying Concentrations of 2,4-D and BA Added on MS Medium. American Journal of Plant Sciences, 7, 2297-2306.

http://dx.doi.org/10.4236/ajps.2016.715202

Received: September 21, 2016

Accepted: November 15, 2016

Published: November 18, 2016

Copyright $\odot 2016$ by author and Scientific Research Publishing Inc. This work is licensed under the Creative Commons Attribution International License (CC BY 4.0).

http://creativecommons.org/licenses/by/4.0/ (c) (i) Open Access

\begin{abstract}
The study aimed to determine the anthocyanin content in callus cultures of Sesbania grandiflora L. (Red Katuray) using petal explants as influenced by 2,4-D and BA. The specific objective of this study is to determine the effect of plant growth regulators specifically auxin (2,4-D) and BA (Benzyladenine) on Murashige and Skoog's (MS) medium in anthocyanin production. Earliest callus initiation was noted in $2.5 \mathrm{ppm}$ to $5.0 \mathrm{ppm}$ 2,4-D without BA and $2.5 \mathrm{ppm} \mathrm{2,4-D}$ with $2.5 \mathrm{ppm}$ BA. Same treatment combination had the highest degree of callus formation and obtained the greatest percentage of callus formation $2.5 \mathrm{ppm} 2,4-\mathrm{D}$ without BA and $2.5 \mathrm{ppm} 2,4-\mathrm{D}$ with $2.5 \mathrm{ppm} \mathrm{BA}$. The heaviest weight of callus was registered at $2.5 \mathrm{ppm} 2,4-\mathrm{D}$ without BA. Significantly higher anthocyanin content was noted in $2.5 \mathrm{ppm}$ to $5.0 \mathrm{ppm} 2,4-\mathrm{D}$ without or with $2.5 \mathrm{ppm} \mathrm{BA}$, with 2.5 and $5.0 \mathrm{ppm} \mathrm{BA}$ and with $5.0 \mathrm{ppm} \mathrm{2,4-D}$ and $2.5 \mathrm{ppm}$ BA. There is a positive relationship between callus formation and anthocyanin production. Results showed that treatments that promoted significantly greater callus formation e.g. $2.5 \mathrm{ppm}$ 2,4-D alone or in combination with $2.5 \mathrm{ppm}$ BA also produced the highest anthocyanin content.
\end{abstract}

\section{Keywords}

Anthocyanin, In Vitro, 2,4-D, BA

\section{Introduction}

The popularity of natural anthocyanin is increasing due to its numerous beneficial effects to human health and well-being. These include protection from DNA cleavage, al- 
tering development of hormone-dependent diseases, enzyme inhibition, regulating immune response, decrease permeability and fragility, and strengthening membrane [1]. Recently, anthocyanin has demonstrated marked ability to reduce cancer cell proliferation and to inhibit tumor formation. Thus, with the importance of anthocyanin, it is important to identify whether processes that will enhance its production are necessary.

Callus cultures as a wide and diverse range of plant genera have been done to produce anthocyanin pigments in vitro. This plant cell culture production system was to explore an alternative resource to establish a protocol that would enhance the production of anthocyanin. Recently, some anthocyanin-producing plant species have been intensively cultured in vitro in order to harness the bioactive pigments and related phytochemicals as medicinally-active compounds. By controlling both the physical and the chemical microenvironment of the plant cell cultures, anthocyanin production is boosted to higher concentrations than available in the parent plant in vivo. One of the most important features of callus culture technology is the production of anthocyanin and other secondary metabolites in a short period, therefore, can be mass produced commercially for continuous supply.

\section{Research Problem}

This experiment dealt with the effect of different concentrations of 2,4-D and Benzyladenine (BA) on callus formation and anthocyanin content.

\section{Materials and Methods (Figure 1)}

\subsection{Media Preparation}

Murashige and Skoog's [2] basal nutrient solution was used for callus induction of petal explant with varying levels of 2,4-D $(0,2.5 ; 5.0 ; 7.5 ; 10 \mathrm{ppm})$ and $\mathrm{BA}(0 ; 2.5 ; 5.0 \mathrm{ppm})$ added singly or in combination. Coconut water $(15 \%)$ was supplied in the medium as additive. Sucrose $(2 \%)$ was added as carbon source. The medium was solidified with agar-agar (0.6\%). Then, the $\mathrm{pH}$ of the medium was adjusted to 5.7. Twenty $\mathrm{ml}$ of aliquots was dispensed in clean culture bottles, covered with autoclavable polyprophylene plastic and paper, and tightened with rubber band. The medium was autoclaved in the pressure cooker for 30 minutes at 15 psi. After autoclaving, the medium was cooled and was inoculated with excised sections of petal explants.

\subsection{Establishment of Sterile Cultures}

Surface sterilized petal explants were cultured on MS basal medium in a bottle. Cultures were incubated under continuous light in an air conditioned room. Contamination and survival were observed, if contaminated, cultures were immediately separated and transferred outside the incubating room.

\subsection{Callus Extraction Procedure}

Callus extraction was done using ethanol as solvent. Twenty-five hundredths (0.25) 


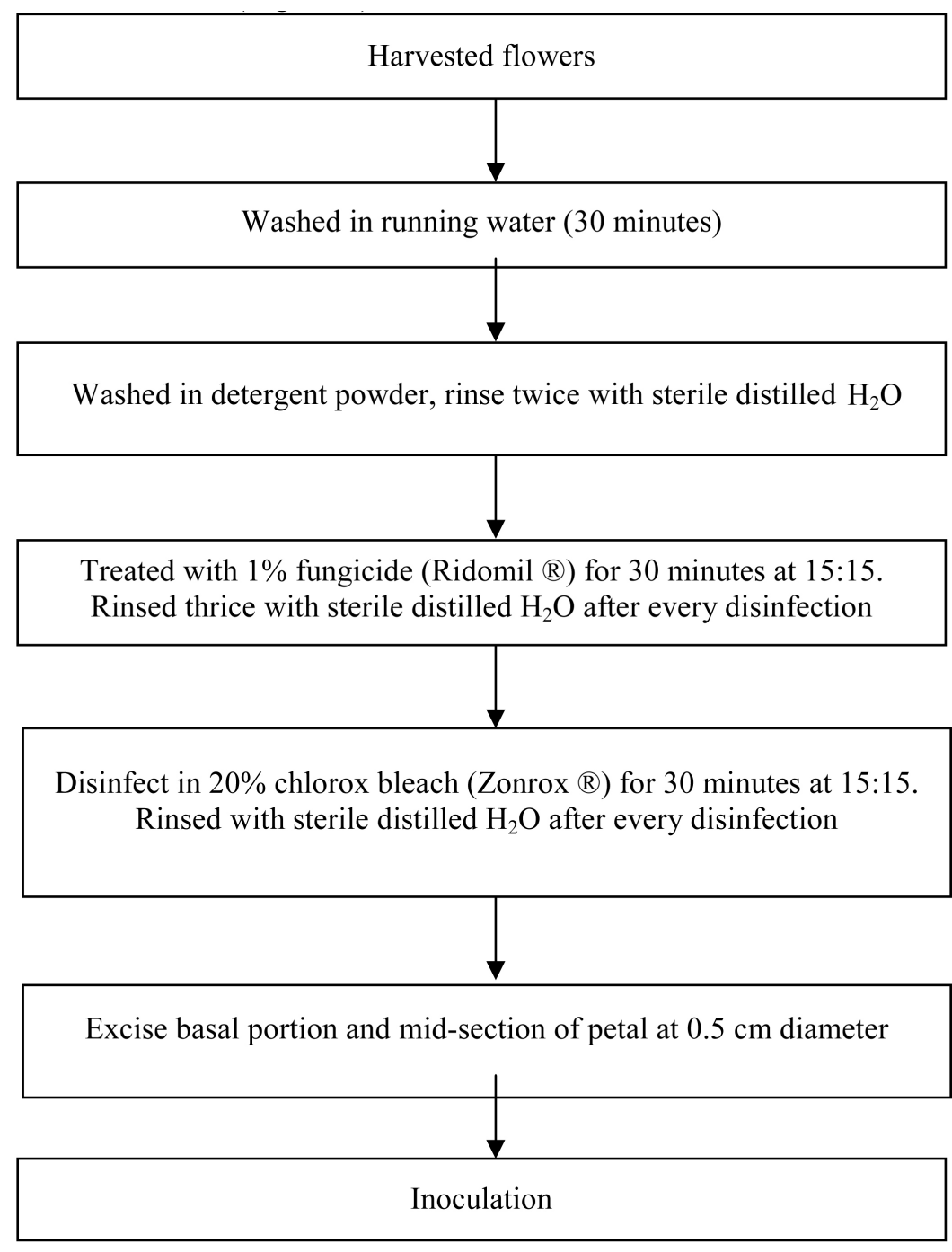

Figure 1. Schematic diagram showing the step-by-step procedure for surface Sterilization of the petal explant of Red Katuray.

grams of callus per sample was placed in a $50 \mathrm{ml}$ Erlenmeyer flask. Every sample was added with $10 \mathrm{ml}$ of ethanol. The callus was thoroughly pulverized with the use of forceps. The mixture was agitated for one hour in a rotary shaker. The extract was transferred in the centrifuge tube and centrifuged at $2000 \mathrm{rpm}$ for 10 minutes. The supernatant were transferred into test tubes.

\subsection{Anthocyanin Analysis}

In anthocyanin analysis, $4 \mathrm{ml}$ of $\mathrm{pH} 1.0 \mathrm{KCl}$ buffer $(125 \mathrm{ml}$ of $0.2 \mathrm{~N} \mathrm{KCl}+385$ of $0.2 \mathrm{~N}$ $\mathrm{HCl}$ ) and $\mathrm{pH} 4.5$ Sodium Acetate Buffer $(400 \mathrm{ml}$ of $1 \mathrm{~N}$ sodium acetate and $240 \mathrm{ml}$ of 1 $\mathrm{N} \mathrm{HCl}$ and $360 \mathrm{ml}$ distilled water were transferred into two individual test tubes and 2 $\mathrm{ml}$ of anthocyanin extract was added and suspended in the buffers. The mixture was homogenized using vortex mixer and equilibrated for 30 minutes. The absorbance in each buffer was taken at 520 and $700 \mathrm{~nm}$ using a spectrophotometer. The final absor- 
bance was then calculated using the formula:

$$
A=\left(A_{520 \mathrm{~nm}, \mathrm{pH}=1}-A_{700 \mathrm{~nm}, \mathrm{pH}=1}\right)-\left(A_{520 \mathrm{~nm}, \mathrm{pH}=4.5}-A_{700 \mathrm{~nm}, \mathrm{pH}=4.5}\right)
$$

Anthocyanin concentration was determined using the formula:

$$
C=(A / E) \times(\mathrm{vol} / 1000) \times M W \times(1 / \text { wt of sample }) \times 10^{6}
$$

where:

$C=$ total anthocyanin $(\mathrm{mg} / \mathrm{kg})$.

$A=$ is absorbance reading.

$E=$ is molar absorptivity of cyanidine 3 -glucoside $=25,965 / \mathrm{cm} \mathrm{M}$.

$V=$ is the final volume of anthocyanin $=10 \mathrm{ml}$.

$M W=$ is the molecular weight of cyanidin 3 glucoside $=449.2 \mathrm{~g} / \mathrm{mole}$.

\section{Results and Discussions}

\subsection{Number of Days to Callus Initiation}

Table 1 shows the number of days to callus initiation of Sesbania grandiflora L. (Red Katuray) explants as influenced by varying concentration of 2,4-D and BA. Results showed that 2,4-D at $2.5 \mathrm{ppm}$ initiated the earliest callus formation with a mean of 9.33 days in the absence of BA. The duration was significantly shorter than the rest of the treatments either as independent or in combinations. It was further observed that the number of days to callus initiation was prolonged with increasing concentration of 2,4-D from $2.5 \mathrm{ppm}$ either with or without BA. The longest period to callus initiation was noted with $10.0 \mathrm{ppm} 2,4-\mathrm{D}$.

Results indicate two important informations. First, 2,4-D is more essential than BA in promoting the initiation of callus in Red Agati cultured in MS medium. This was exhibited by the significantly shortest number of days to callus initiation when $2.5 \mathrm{ppm}$ 2,4-D was applied without BA. The reverse occurred when only BA was applied either at 2.5 or $5.0 \mathrm{ppm}$. Callus initiation was delayed by almost 20 days, the longest period.

Second, increasing concentration of $2,4-\mathrm{D}$ from $2.5 \mathrm{ppm}$ to $10 \mathrm{ppm}$ at same BA

Table 1. Number of days to callus initiation of Sesbania grandiflora L. (Red Katuray) as influenced by 2,4-D and BA.

\begin{tabular}{ccccc}
\hline \multirow{2}{*}{$\begin{array}{c}2,4-\mathrm{D} \\
(\mathrm{ppm})\end{array}$} & \multicolumn{3}{c}{ BA (ppm) } & Mean \\
\cline { 2 - 4 } & 0 & 2.5 & 5.0 & $18.56^{\mathrm{A}}$ \\
\hline 0 & $0.00^{\mathrm{g}}$ & $27.33^{\mathrm{a}}$ & $28.33^{\mathrm{a}}$ & $11.44^{\mathrm{E}}$ \\
2.5 & $9.33^{\mathrm{f}}$ & $11.67^{\mathrm{e}}$ & $13.33^{\mathrm{cd}}$ & $12.78^{\mathrm{D}}$ \\
5.0 & $11.33^{\mathrm{e}}$ & $12.33^{\mathrm{de}}$ & $14.67^{\mathrm{cd}}$ & $14.56^{\mathrm{C}}$ \\
7.5 & $13.00^{\mathrm{de}}$ & $14.33^{\mathrm{cd}}$ & $16.33^{\mathrm{bc}}$ & $16.00^{\mathrm{B}}$ \\
10.0 & $14.33^{\text {cd }}$ & $15.67^{\mathrm{bc}}$ & $18.00^{\mathrm{b}}$ & \\
Mean & $9.60^{\mathrm{c}}$ & $16.27^{\mathrm{b}}$ & $18.13^{\mathrm{a}}$ &
\end{tabular}

Means not sharing letter in common within the cells (a-g), within a column mean (A-E) and within a mean (X, Y, Z) at the $5 \%$ probability level differ significantly by duncan's multiple range test. 
concentration significantly prolonged callus initiation. Alejar and Sese (1999) reported that the physiological effect of auxin (the active ingredient of 2,4-D) and cytokinin (the active ingredient of $\mathrm{BA}$ ) was the promotion of cell division. Callus is a consequence of cell division. As early as 1979, Bidwell reported that cell division is very much under the control of hormones. He said that in the absence of kinetin, auxin causes cell enlargement in cultured tissue. However, excess auxin suppresses onset of metaphase.

Plant growth regulators like 2,4-D and BA which contain auxin and cytokinins, respectively, are essential to effect differentiation, growth and development of an organ or organism. This condition was exhibited by the result of the study when no callus was formed without the two growth regulators. These results corroborated the findings of Suriender et al. (2006) that no callus was formed from the petiole, leaf and petal explants of gerbera family without 2,4-D and BA. When 2,4-D and BA were supplemented to MS basal medium, callus initiation occurred. This also corroborated with the findings of Bosila et al. (1993) that addition of BA at $0.5 \mathrm{mg} / \mathrm{liter}$ and 2,4-D at $5.0 \mathrm{mg} / \mathrm{l}$ induced callus formation on leaves cultured in aseptic MS basal solid medium. However, 2,4-D can only be beneficial at a certain level (Sheeba et al., 2003).

\subsection{Degree of Callus Formation}

Table 2 presents the degree of callus formation of Sesbania grandiflora L. (Red katuray) as influenced by $2,4-\mathrm{D}$ and BA. The degree of callus formation was enhanced in 2.5 ppm 2,4-D without BA supplemented in the culture medium. Results showed that highest degree of callus formation as affected by the different concentrations of 2,4-D and BA was obtained by the treatment combination of $2.5 \mathrm{ppm} 2,4-\mathrm{D}$ and $0 \mathrm{ppm} \mathrm{BA}$ with an average of 3.60 and the lowest was incurred by a treatment combination of 0 ppm 2,4-D with 2.5 to 5.0 ppm BA.

Callus formation was affected by the presence of both an auxin and cytokinin in the medium. Optimal growth depends on the ratio of cytokinin/auxin as well as the total amount of plant growth regulators in the medium (King, 2004).

Table 2. Degree of callus formation of Sesbania grandiflora L. (Red Katuray) as influenced by $2,4-\mathrm{D}$ and BA.

\begin{tabular}{ccccc}
\hline \multirow{2}{*}{$\begin{array}{c}2,4-\mathrm{D} \\
(\mathrm{ppm})\end{array}$} & \multicolumn{3}{c}{$\mathrm{BA}(\mathrm{ppm})$} & Mean \\
\cline { 2 - 4 } 0 & $1.00^{\mathrm{e}}$ & 2.5 & 5.0 & $1.67^{\mathrm{D}}$ \\
\hline 2.5 & $3.60^{\mathrm{a}}$ & $3.23^{\mathrm{ab}}$ & $2.00^{\mathrm{d}}$ & $3.31^{\mathrm{A}}$ \\
5.0 & $3.17^{\mathrm{ab}}$ & $3.13^{\mathrm{ab}}$ & $3.10^{\mathrm{ab}}$ & $2.79^{\mathrm{B}}$ \\
7.5 & $2.87^{\mathrm{bc}}$ & $2.37^{\mathrm{cd}}$ & $2.07^{\mathrm{d}}$ & $2.59^{\mathrm{B}}$ \\
10 & $2.37^{\mathrm{cd}}$ & $2.10^{\mathrm{d}}$ & $2.53^{\mathrm{cd}}$ & $2.18^{\mathrm{C}}$ \\
\hline Mean & $2.60^{\mathrm{X}}$ & $2.57^{\mathrm{X}}$ & $2.07^{\mathrm{d}}$ & \\
\hline
\end{tabular}

Means not sharing letter in common within the cells (a-e), within a column mean (A-D) and within a mean (X, Y) at the $5 \%$ probability level differ significantly by Duncan's Multiple Range Test. Note: Scale: (no callus formation; 2.00 (slight: 1\% - 50\%); 3.00 (moderate: 51\% - 75\%); 4.00 (profuse: 76\% - 100\%). 
The above findings corroborate with the report of Sheeba et al. (2003) that 2,4-D can induce callus formation up to a certain level $(2.0-3.0 \mathrm{mg} / \mathrm{l})$. This was also the report of Ling (2008) using full strength MS media supplemented with either $1 \mathrm{mg} / \mathrm{l}$ to $5 \mathrm{mg} / \mathrm{l}$ of picloram or $1 \mathrm{mg} / \mathrm{l}$ to $3 \mathrm{mg} / \mathrm{l}$ of 2,4-D. He found that the above supplement was the most efficient media formation for the establishment of cell suspension culture.

\subsection{Percentage of Callus Formation}

Table 3 shows percentage callus formation of Sesbania grandiflora L. (Red Katuray) as influenced by 2,4-D and BA. The effectiveness of 2,4-D applied alone at $2.5 \mathrm{ppm}$ or in combination with $2.5 \mathrm{ppm}$ BA was prominently exhibited in percentage callus formation. These treatment combinations registered a similar mean callus formation of 96.67 percent.

The high percentage of callus formation in the MS culture medium applied with 2,4-D especially at $2.5 \mathrm{ppm}$ seems to be an off shoot of the high degree of callusing. The said treatment had a 3.60 degree of callusing with a description of moderate to profuse which could have been enhanced by the early and rapid initiation of cells as presented earlier. Lang (2008) reported that the highest mean percentage of callus formation in leaf explants of gerbera cultivars was obtained by the combined application of $2 \mathrm{ppm}$ 2,4-D and 1 ppm BA.

Results also consistently showed that while $2,4-\mathrm{D}$ is essential in callus formation at lower concentration of $2.5 \mathrm{ppm}$, the higher concentration of $5.0 \mathrm{ppm}$ and $10.00 \mathrm{ppm}$ seems to indicate inhibitory effect. They exhibited significantly inferior data from days to callus initiation to percentage of callus formation. On the other hand, higher concentration of 2,4-D inhibit the growth of the apical hook region of etiolated Pisumsativum seedlings $60 \%$ or by stopping almost cell divisions. Cells are prevented from entering prophase. Higher concentration also retarded the cell division in intact root tips and completely stopped the process in lateral buds [3].

Table 3. Percentage callus formation of Sesbania grandiflora L. (Red Katuray) as influenced by $2,4-\mathrm{D}$ and $\mathrm{BA}$.

\begin{tabular}{ccccc}
\hline $\begin{array}{c}2,4-\mathrm{D} \\
(\mathrm{ppm})\end{array}$ & \multicolumn{3}{c}{$\mathrm{BA}(\mathrm{ppm})$} & Mean \\
\cline { 2 - 4 } & 0 & 2.5 & 5.0 & \\
\hline 0 & $0.00^{\mathrm{d}}$ & $80.00^{\mathrm{bc}}$ & $76.67^{\mathrm{bc}}$ & $52.22^{\mathrm{D}}$ \\
2.5 & $96.67^{\mathrm{a}}$ & $96.67^{\mathrm{a}}$ & $83.33^{\mathrm{bc}}$ & $92.22^{\mathrm{A}}$ \\
5.0 & $93.33^{\mathrm{ab}}$ & $86.67^{\mathrm{abc}}$ & $80.00^{\mathrm{bc}}$ & $86.67^{\mathrm{A}}$ \\
7.5 & $86.67^{\mathrm{abc}}$ & $80.00^{\mathrm{bc}}$ & $66.67^{\mathrm{c}}$ & $77.78^{\mathrm{B}}$ \\
10 & $76.67^{\mathrm{bc}}$ & $70.00^{\mathrm{c}}$ & $63.33^{\mathrm{c}}$ & $70.00^{\mathrm{C}}$ \\
\hline Mean & $70.67^{\mathrm{Y}}$ & $82.67^{\mathrm{X}}$ & $74.00^{\mathrm{Y}}$ & \\
\hline
\end{tabular}

Means not sharing letter in common within the cells (a-d), within a column mean (A-D) and within a mean (X, Y) at the $5 \%$ probability level differ significantly by Duncan's Multiple Range Test. 


\subsection{Callus Growth}

Growth of callus in terms of weight at various stages also resembles the sigmoid growth curve e.g. an initial slow growth followed by rapid growth and then a decline or leveling off. During the 3rd week, the weight of callus disregarding that of the control/(0 ppm) ranged from 0.08 to $0.14 \mathrm{~g}$. A marked increase occurred on the 6th week. The weight during this period ranged from 0.81 to $1.25 \mathrm{~g}$ or an increase of more or less $80 \%$ to more than $100 \%$. Thereafter, on the 9th week, there was a decrease in weight compared to the 6th week weights. The weight of the callus during the said period ranged from 0.97 to 1.51 or an increase of approximately eight to nine \% over the weight during the 6th week. Apparently, this stage is the prelude to cell differentiation.

The above results (Figure 2) were clearly reflected in the combined effect of 2,4-D and BA. With 2,4-D alone ( $0 \mathrm{ppm} \mathrm{BA}$ ) at $2.5 \mathrm{ppm}$, the highest weight of callus was obtained which was significantly higher over all other treatment combinations. Other treatment combinations have more or less similar effect at same concentration of both. Results of the study are similar to the findings of Taha [4] from catharanthus internode explants wherein there was an increase of growth of around 125\% during the second sub-culture from $0.25-1.45 \mathrm{~g}$.

\subsection{Anthocyanin Content}

Table 4 presents the anthocyanin content of Sesbania grandiflora L. (Red katuray) as influenced by 2,4-D and BA. Results of the study revealed that highest anthocyanin content was obtained from the treatment combination 2.5 to $5.00 \mathrm{ppm} 2,4-\mathrm{D}$ with 2.5 ppm BA with average means of $448.66 \mathrm{mg} / \mathrm{kg}$ and $426.73 \mathrm{mg} / \mathrm{kg}$, respectively. Results

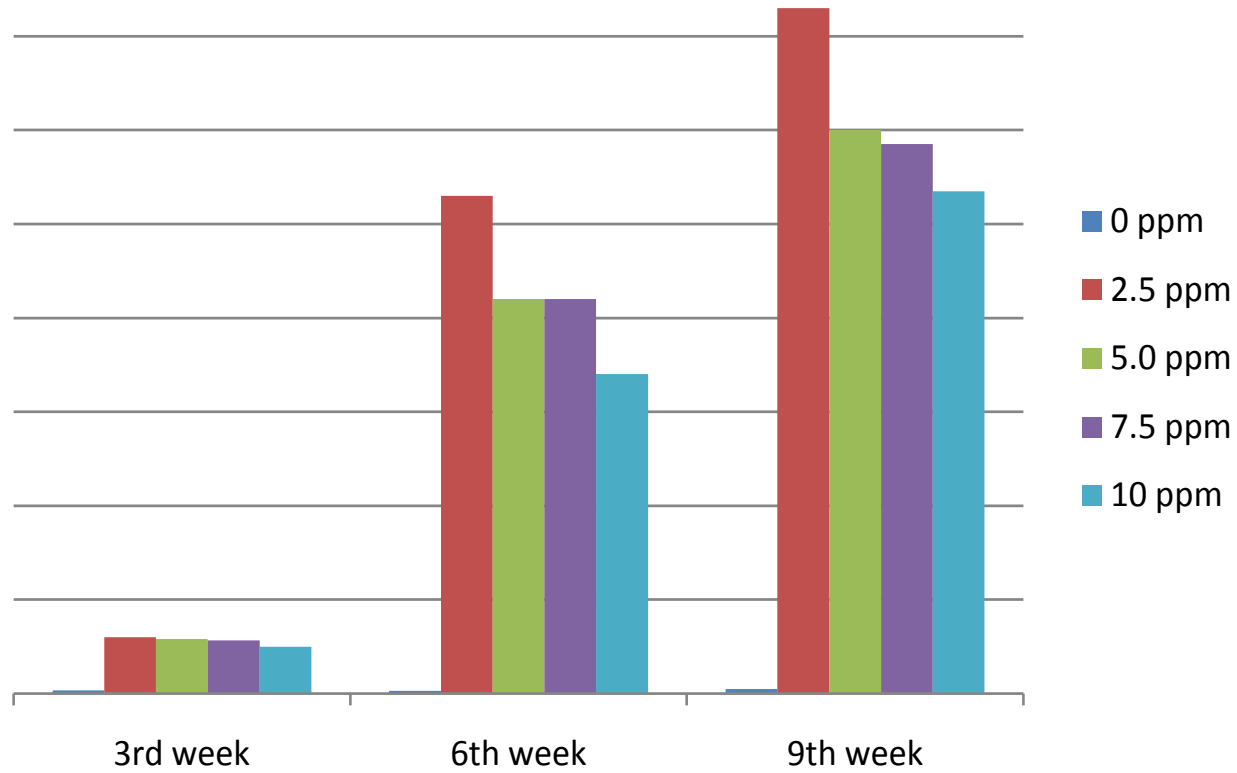

Figure 2. Presents the results of callus weight of Sesbania grandiflora L. as influenced by 2,4-D and $\mathrm{BA}$ on the 3rd to 9 th week after inoculation. 
Table 4. Anthocyanin content of Sesbania grandiflora L. (Red katuray) as influenced by 2,4-D and BA on 21 days after the 3rd sub-culture in terms of $\mathrm{mg} / \mathrm{kg}$.

\begin{tabular}{ccccc}
\hline $\begin{array}{c}2,4-\mathrm{D} \\
(\mathrm{ppm})\end{array}$ & 0 & 2.5 & BA $(\mathrm{ppm})$ & Mean \\
\cline { 2 - 4 } & $5.99^{\mathrm{h}}$ & $129.00^{\mathrm{g}}$ & $182.23^{\mathrm{efg}}$ & $105.74^{\mathrm{E}}$ \\
2.5 & $289.49^{\mathrm{cd}}$ & $448.66^{\mathrm{a}}$ & $403.67^{\mathrm{ab}}$ & $380.60^{\mathrm{A}}$ \\
5.0 & $247.97^{\mathrm{de}}$ & $426.73^{\mathrm{a}}$ & $334.47^{\mathrm{bc}}$ & $336.39^{\mathrm{B}}$ \\
7.5 & $249.12^{\mathrm{de}}$ & $232.67^{\text {def }}$ & $259.43^{\mathrm{d}}$ & $247.08^{\mathrm{C}}$ \\
10 & $156.84^{\mathrm{g}}$ & $166.08^{\mathrm{fg}}$ & $152.24^{\mathrm{g}}$ & $158.39^{\mathrm{D}}$ \\
Mean & $189.88^{\mathrm{Y}}$ & $280.63^{\mathrm{X}}$ & $266.41^{\mathrm{X}}$ & \\
\hline
\end{tabular}

Means not sharing letter in common within the cells (a-g), within a column mean (A-E) and within a mean (X, Y, Z) at the $5 \%$ probability level differ significantly by Duncan's Multiple Range Test.

further showed that in the absence of both 2,4-D and BA in the culture medium production of anthocyanin can be considered neglible at $5.99 \mathrm{mg} / \mathrm{kg}$.

Anthocyanins are secondary metabolites found in higher plants that contribute to the colors of flowers and fruits. They are glucosides of anthocyanidins, water soluble vacuolar pigments that may appear red, purple or blue according to ph. They belong to a class of molecules called flavonoids synthesized via phenylpropanoid pathway. They occur in all tissues of higher plants, including leaves, stems, roots, and flowers (Hershey, 2001).

Regarding the optimum concentration in this study, the highest production of anthocyanin was noted with the addition of 2.5 to $5.0 \mathrm{ppm}$ of both 2,4-D and BA in the culture medium. The lowest production was in culture medium supplied only with BA without 2,4-D. Anthocyanin content was only limited below the $200 \mathrm{mg} / \mathrm{kg}$ level. However, both 2,4-D and BA can only be beneficial at a certain level (Sheeba et al., 2003).

There seems to be a positive relationship between callus formation and anthocyanin content. It was observed that treatments which promoted higher callus formation produced higher anthocyanin. It is worth mentioning that among the interactions between 2,4-D and BA, the concentration of $2.5 \mathrm{ppm}$ of both plant growth regulators produced the highest percentage of callus formation. The same treatment combinations produced the highest anthocyanin at $448.66 \mathrm{mg} / \mathrm{g}$. As callus formation declined, so with the anthocyanin content. Mori [5] [6] mentioned that without the 2,4-D and BA in the strawberry suspension cultures, low anthocyanin could be produced. When the two plant growth regulators were added in the medium, substantial anthocyanin production occurred.

The effects of 2,4-D and BA on anthocyanin production differed greatly, as influenced by concentration. Taha [4] reported that the best result of callus and anthoyanin production was obtained using leaf explant of Fragariaanannasa which were cultured on MS medium containing $1 \mathrm{mg} / \mathrm{L}$ 2,4-D and $1 \mathrm{mg} / \mathrm{L} \mathrm{BA}$. Kim (2002) revealed that MS basal medium supplemented with $0.5 \mathrm{mg} / \mathrm{L} \mathrm{BA}$ with $0.1-1.0 \mathrm{mg} / \mathrm{L}$ 2,4-D using Sheri- 
dan grape promoted anthoycanin production. The differences in the results of the different species might be due to the variation of plants (Kim, 2002) it might be due to the structural genes encoding the enzymes of the anthocyanin biosynthetic pathway (Holon et al., 1995; Solfanelli et al., 2006; Teng et al., 2005). It was further revealed by (Quarocchio et al., 1993) and their expression is regulated by several regulator genes.

\section{Summary, Conclusion and Recommendation}

The general objective of the study was to determine the anthocyanin content of callus cultures of Sesbania grandiflora L. (Red Katuray) in MS medium using petal explants as influenced by 2,4-D and BA.

The plant growth regulators were 2,4-D (auxin-containing synthetic hormone and Benzlyl adenine (BA) which contains cytokinin, another known growth promoter. Concentrations of $0,2.5,5.0,7.5$ and $10.0 \mathrm{ppm}$ of 2-4,D and 0, 2.5 and $5.0 \mathrm{ppm}$ of BA added in the Murashige and Skoog (MS) [2] culture medium were examined.

Results show that application of 2,4-D was more beneficial than BA in terms of number of days to callus initiation. Applying 2,4-D especially at $2.5 \mathrm{ppm}$ even without BA significantly shortened callus initiation. Increasing the concentration of 2,4-D at any BA concentration prolonged the number of days to callus initiation. The reverse occurred when BA at 2.5 and $5.0 \mathrm{ppm}$ was applied. Duration of callus initiation was prolonged.

The early callus initiation in $2.5 \mathrm{ppm} 2,4-\mathrm{D}$ and BA promoted higher degree of callus formation. Addition of $2.5 \mathrm{ppm}$ 2,4-D alone or in combination with the same concentration of BA triggered moderate to profuse production of callus.

As a consequence, highest percentage callus formation was noted in the culture medium supplemented with $2.5 \mathrm{ppm} 2,4-\mathrm{D}$ with $0 \mathrm{ppm}$ BA. Applying BA alone did not change the percentage callus formation. Moreover, result showed that 2,4-D at higher level of $7.5 \mathrm{ppm}$ and $10.00 \mathrm{ppm}$ had a depressing effect on callus formation. The weight of callus increased from the 3rd week to the 6th week and then declined on the 9th week.

There is a positive relationship between callus formation and anthocyanin production. Results showed that treatments that promoted significantly greater callus formation e.g. $2.5 \mathrm{ppm}$ 2,4-D alone or in combination with $2.5 \mathrm{ppm} \mathrm{BA}$ also produced the highest anthocyanin content.

\section{References}

[1] Lila, M. (2004) Anthocyanin and Human Health: An In Vitro Investigative Approach. Journal of Biomedicine and Biotechnology, 5, 306-313. https:/doi.org/10.1155/S111072430440401X

[2] Murashige, T. and Skoog, F. (1962) A Revised Medium for Rapid Growth and Bioassay with Tobacco Tissue Culture. Plant Physiology, 15, 473-497. https:/doi.org/10.1111/j.1399-3054.1962.tb08052.x

[3] Pelbaum, A. and Burg, S.P. (1971) Effect of Ethylene on Cell Division and Deoxyribonucleic Acid Synthesis in Pisumsativum. Plant Physiology, 50, 117-124. 
https:/doi.org/10.1104/pp.50.1.117

[4] Taha, H.S., El-Rahman, A., Fathalia, M. and Karem, A. (2008) Succesful Application for Enhancement and Production of Anthocyanin Pigment from Calli Cultures of Some Ornamental Plants. Australian Journal of Basic and Applied Sciences, 2, 1148-1156.

[5] Mori, T., Sakurai, M., Shigeta, J. and Yoshida, K. (1993) Formation of Anthocyanins from Cells Cultured from Different Parts of Strawberry Plants. Journal of Food Science, 58, 788793. https:/doi.org/10.1111/j.1365-2621.1993.tb09359.x

[6] Mori, T. and Sakurai, M. (1994) Use of Auxin and Cytokinin to Regulate Production and Composition from Strawberry Cell Suspension Cultures. Journal of Food Science and Agriculture, 65, 271-276. https:/doi.org/10.1002/jsfa.2740650303

\section{Submit or recommend next manuscript to SCIRP and we will provide best service} for you:

Accepting pre-submission inquiries through Email, Facebook, LinkedIn, Twitter, etc. A wide selection of journals (inclusive of 9 subjects, more than 200 journals)

Providing 24-hour high-quality service

User-friendly online submission system

Fair and swift peer-review system

Efficient typesetting and proofreading procedure

Display of the result of downloads and visits, as well as the number of cited articles

Maximum dissemination of your research work

Submit your manuscript at: http://papersubmission.scirp.org/

Or contact ajps@scirp.org 